\title{
Assessing the fourth wave of the populist radical right: Jair Bolsonaro's voters in comparative perspective
}

\author{
Lisa Zanotti ${ }^{1}$ \\ José Rama ${ }^{2}$ \\ Talita Tanscheit ${ }^{3}$
}

\begin{abstract}
The determinants of the vote for the populist radical right (PRR) have been thoroughly studied especially in Western and Eastern Europe. However, the PRR has become a global phenomenon. At this point, comparative studies are essential in order to advance in the understanding of the success of this party family. For this reason, in this paper, we analyze the individual factors that help to understand the support for Jair Bolsonaro in the last 2018 Presidential elections in Brazil at the light of the findings for the PRR in Western Europe. The aim is twofold. First, we contribute to the comparative literature on the determinants for the vote for the PRR in a non-European country. Second, we also assess, if any, the peculiarity of the vote for the PRR in Latin America and specifically in the Brazilian case. In order to carry on our analysis, we used the European Election Studies (EES) dataset for Western European parties and data from the Estudio Electoral Brasileño for Brazil (ESEB). The main results show that religion (evangelists), race (white), income (high), and, above all, negative views of the main opposition party (Partido dos Trabalhadores [PT] - Worker's Party), i.e., antipetismo, are the main reasons to understand the vote for Bolsonaro in the 2018 Presidential elections.
\end{abstract}

\section{Key words}

Populist radical right, Brazil, Western Europe, negative identities, democracy

\footnotetext{
${ }^{1}$ Corresponding Author, Diego Portales University, Santiago de Chile [lisa.zanotti@mail.udp.cl]

${ }^{2}$ Universidad Autónoma de Madrid [jose.rama@uam.es]

${ }^{3}$ Federal University of Rio de Janeiro [talitastt@gmail.com]
} 


\section{Introduction}

Populism has been a classic feature in Latin America (de la Torre and Arnson, 2013; Madrid, 2012; Roberts, 2006). However, except few relevant studies (see Mudde and Rovira Kaltwasser, 2012; Meléndez and Rovira Kaltwasser, 2019), the contemporary comparative literature that worked with the ideational approach of populism has mainly focused on Europe (Hawkins and Rovira Kaltwasser, 2019; Mudde and Rovira Kaltwasser, 2013). This occurred mainly for two reasons.

First, due to the presidential features of the region and the low levels of party institutionalization the populist discourse in Latin America has been mainly articulated by political personalities. This is why the so called political institutional approach has been used the most to analyze the phenomenon in the region. This approach defines populism as "political strategy through which a personalistic leader seeks or exercises government power based on direct, unmediated, un-institutionalized support from large numbers of mostly unorganized followers" (Weyland, 2001:14). Differently, the ideational approach, conceiving populism as a set of ideas, maintains that it can be articulated by leaders, parties or social movements (Mudde and Rovira Kaltwasser, 2017:42). Indeed, in Western Europe, from the organizational point of view, populist discourse is mainly articulated by political parties. Parties such as National Rassemblement (former Front National) in France, The Freedom Party of Austria (FPÖ) and the (Northern) League in Italy are examples of long-lasting political parties. ${ }^{4}$ Secondly, populism scholars have mainly focused on a specific family, namely the populist radical right (PRR). It combines, at least, three ideological traits: nativism, authoritarianism and populism (Mudde, 2007). As a consequence, even if populism has been a feature of the continent for a decade, this is not the case of the PRR, which only achieved a limited diffusion in Latin America (Zanotti and Roberts, 2021).

Historically, scholars have identified three waves of populism in the continent which differ in respect to the so called "host" ideologies to which populism attached, such as socialism, neoliberalism or nativism (Mudde and Rovira Kaltwasser, 2017). Depending on the "host" ideology the categories of "the people" and "the elites" assume different connotations. With respect to this, some scholars referred to these categories as floating signifier, i.e., empty containers with no clear meanings. Looking at the three waves of

\footnotetext{
${ }^{4}$ The Front National since 1972, the PFÖ since 1956 and the Northern League since 1991.
} 
Latin American populism, we can see examples in the conceptualizations of "the people" and "the elite" (Laclau, 2005; Rovira Kaltwasser, 2014).

The first wave, between the 1930s and the 1960s, saw the rise of populist leaders such as Juan Domingo Perón in Argentina and Getúlio Vargas in Brazil. The people consisted mainly of the natural base of the left, the urban and the rural poor. At the same time, the elite were depicted as those "that opposed the expansion of the state, the nationalization of the economy and the implementation of protectionist trade policies" (Rovira Kaltwasser, 2014: 498).

The second wave, between the 1980s and the 1990s, was characterized by the use of neoliberal discourse. Examples of leaders that incarnated this discourse are Carlos Menem in Argentina and Albert Fujimori in Peru. Here the people were seen as a passive mass of individuals. On the other hand, the elite was represented by "those actors who profited from the state-led development model and were opposed to the implementation of the policies of the so-called Washington Consensus" (Rovira Kaltwasser, 2014: 498).

Finally, in the third wave, beginning at the end of the 1990s, populist leaders strongly opposed neoliberal discourse and free-market policies, instead appealing to the ideology of Americanismo. The discourse of leaders like Hugo Chávez in Venezuela, Evo Morales in Bolivia and Rafael Correa in Ecuador shared a radical left host ideology. As a consequence, the people then became all those discriminated against and excluded while the elite became "the defenders of neoliberalism and the political actors who support a Western model of democracy that is not suitable for Latin America" (Rovira Kaltwasser, 2014: 499).

In sum, even if in Latin America populism combined with a rightist ideology such as neoliberalism in the 1990s, populist leaders did not articulate nativist ideas in populist fashion. Things started to change in 2017. In Chile, the former Independent Democratic Union (UDI) congressman José Antonio Kast left the party to run for President as an independent. With a discourse similar to the PRRPs in Europe, he surprisingly obtained almost the 8 percent in the presidential election. Less than a year later, with a similar discourse, Jair Bolsonaro, a former Army Captain, led the Social Liberal Party (PSL) to power, and became the first PRR president in the region. Bolsonaro gained the presidency obtaining more that 46 percent of the vote in the first round and the 55,1 in the second. 
Surprisingly, besides the phenomenon of the rise of Bolsonaro being the object of different studies, (see Hunter and Power, 2019; Santos and Tanscheit, 2019; Rennó, 2020; Leyton et. al., 2021; Setzler, 2021), it has not been analyzed in a comparative perspective. This study aims to contribute to fill an important gap in the literature on the determinant of the vote for PRRPs analyzing a non-European case and comparing it with four well-known European PRRPs: Alternative for Germany (AfD), French National Rally (RN), Italian Lega and Austrian Party for Freedom (FPÖ). This is relevant because to use Cas Mudde's words “theoretical innovation, particularly with regard to explanations of the electoral success of populist radical right parties, has been marginal since early 1990s" (2017: 1). The article makes a step int this direction, relying on the literature of the determinant of the vote for PRR in Europe and analyzing the similarities and difference with the respect to the voter of Jair Bolsonaro in Brazil.

\section{Party system transformation in Western Europe and the emergence of populist radical right parties}

The decline of traditional parties (Ignazi, 2017) as main actors to articulate the traditional cleavages (Franklin et al 1992) and respond to voter's demands, started various decades ago and is connected with long-standing processes of institutional dealignment and sociological realignment. Regarding the dealignment process, the wellknown "cartel party" (Katz and Mair, 1995) posits that traditional political parties have become, especially since the late 1980s, "state agencies" failing to represent voters' interests (van Biezen, 2004). As a consequence of parties' withdrawal from institutions, as well as of the convergence of mainstream (left and right) parties towards the centre of the political spectrum (Morgan, 2013; Roberts, 2017), important segments of the electorate have become susceptible to be attracted to the markedly different policies put forward by the radical/populist parties.

Another school of thought emphasizes sociological (rather than institutional) factors to understand the current success of PRRPs. In this regard, globalization and secularization, common to all Western democracies since the late 1970s, has brought important changes in society. Thus, contrary to what - at least until the late 1980s - had been the norm in Europe, where the structure of inter-party competition in a given country was determined by its cleavage structure (Lipset and Rokkan, 1967; Bartolini and Mair, 1990), the decline of cleavages has led to a process where the appearance of new dimensions of competition (e.g. migration, Europeanization), less socially rooted, 
have produced a decrease in party identification and at reduction in electoral stability (Dalton and Weldon, 2005).

These institutional and sociological explanations of PRRPs' success in Western Europe are directly connected with some of the explanations at the individual level, i.e., those demand-level factors that help to understand the probabilities of voting for such political options. It can be said that, to a certain extent, there is an archetype of PRR voter who, affected by the collapse of traditional parties and the decline of traditional cleavages as well as due to the consequences of the process of globalization and denationalization, find in the populist rhetoric of easy solutions to big problems, the best option.

\section{Who votes for the populist radical right in Western Europe?}

With respect to the profile of PRRPs at least two main theories were developed in order to understand their growing support and the entrance in the so-called fourth wave of farright currently underway (Mudde, 2019). On the one hand, the rise of PRRPs has been explained by the decline in the economic conditions at the aggregate level (Funke et. al., 2016). On the other hand, other studies pointed at the role of cultural rather than economic factors to understand both, the decline on the support for mainstream parties and the boost in the share of votes for fringe political options (Hernández and Kriesi, 2016). Taking these perspectives into account, we address the extent to which Bolsonaro voters share some commonalities with PRRPs voters in Western Europe. In this sense, although we know that does not exist such a thing as "the populist radical right voter", and that one should be careful with the extrapolation of findings on the voter's profile from one populist party to another (Rooduijn, 2018), following the literature on PRRPs voters we test the lowest common denominator of its supporters. Our analysis takes into account the effect of sociodemographic factors, economic grievances (Mols and Jetten, 2016), nativist attitudes (Mudde, 2007), anti-immigration feelings (Ivarsflaten, 2008), anti-establishment sentiments (Meléndez and Rovira Kaltwasser, 2019), and attitudes towards democracy (Rovira Kaltwasser and van Hauwaert, 2020) upon the probability to vote for four well-know PRRPs: AfD, FPÖ, RN and Lega compared with the Brazil PRR leader Jair Bolsonaro.

\section{Socio-demographic factors}

One could say that the PRR family is quite widespread in Western Europe. Parties like $\mathrm{RN}$ in France date back to the 1970s and the Northern League in Italy competed for the 
first time at the national level in 1992. During the last decade the populist radical right emerged also in those countries that, for different reasons, seem to have been immune to it. This is for example the case of AfD in 2016 (Berbuir, Lewandosky and Siri, 2015) VOX in Spain in $2018^{5}$ (Rama et al., 2021) and Chega in Portugal in 2019 (Mendes and Dennison, 2020). What those who voted for these parties have in common? First, from the sociodemographic point of view scholar have found that man (Lubbers et al, 2002), with low levels of education are more prone to vote for the PRR. Also, although it exists a certain debate, (van Hauwaert and van Kessel, 2018) most studies found that populist radical right forces are also voted by middle-class and younger people (Arzheimer, 2018).

\section{Economic grievances}

Whereas at the aggregate level, contributions such as the ones of Funke and collaborators (2015) or Dalio and others (2017) find a relationship between the post 2008 Great Recession economic downturn and the rise of support for radical (also populist) options, at the individual level this relationship is apparently more difficult to demonstrate. Rico and Anduiza (2019) emphasize that is the perception that the country's economy poor performance which led voters to listen the siren songs of populist leaders. On this same note Mols and Jetten (2016) find that perceptions more than real difficult economic conditions, explain the support for PRRPs. Going a step further, combining macro and micro level explanations, Rooduijn and Burgoon (2017: 18) argue that those who experience economic difficulties are only more likely to vote for a populist radical right party if the unemployment rate of a country is low, the gross domestic product per capita is high and if inequality levels are low.

\section{Nativism and attitudes towards immigration}

As Mudde points out nativism, which results from a combination of nationalism and xenophobia, is the key ideology of the populist radical right party family at least in Western Europe. Nativism, "holds that states should be inhabited exclusively by members of the native group (the nation) and that nonnative (or alien) elements, whether persons or ideas, are fundamentally threatening to the homogeneous nation state" (Mudde, 2019: 27). Nativism tends translate in preferences for harsher policy

\footnotetext{
${ }^{5}$ Even if officially VOX emerged in 2013 it was only with the Andalusian election of December 2018 that we can consider it as a relevant competitor in the Spanish system.
} 
proposals about immigration which is discouraged in order to "save" the allegedly homogeneous nation state. In line with this, various studies have demonstrated that antiimmigration feelings are a driver for the vote the populist radical right (Iversflaten, 2008).

Using data from the United Kingdom, Kaufmann (2017) contends that it would be changes in levels of immigration instead of immigration per se to boost support for the populist radical right. However, as Eatwell and Goodwin (2018) have remarked, populist right-wing parties have gained ground not only in countries that have experienced rapid and profound ethnic shifts like the United Kingdom, but also in those that have much lower levels of immigration, like Hungary and Poland. This has led to distinguishing between objective immigration figures and the subjective perceptions associated with them. As Norris and Inglehart put it: "what matters for cultural attitudes and electoral behavior is not just the number of migrants who arrive, but public perceptions of them" $(2019,181)$. Also, in a meta-analysis of 326 quantitative models from 46 studies of Western Europe covering the 1995-2016 period, Stockemer and collaborators (2018) found that both attitudes towards immigration and racial attitudes were by far the variables that studies used more frequently to predict the vote for PRRPs, and that they had the second highest success rate as explanatory factors, only surpassed by gender.

\section{Authoritarianism and law and order}

As we have previously mention in the introduction, authoritarianism is one of the central ideological traits of the PRR. Authoritarianism, namely "belief in a strictly ordered society in which infringements to authority are to be punished severely" tends to translate into preferences for stricter "law and order" measures (Mudde and Rovira Kaltwasser 2017: 34) with, for example, calls for more police with greater competencies and less political involvement of the judiciary (Mudde 2017: 4).

With respect to this Betz (1994) who describes two categories of "radical right-wing populist parties," those that emphasize neo-liberal themes, and those emphasizing authoritarian / nationalist themes. At the individual level the study of Donovan (2019) shows that in multiparty systems people with authoritarian attitudes were more likely to be supporters of smaller radical right parties. Importantly enough, he demonstrates that authoritarian attitudes were a notable predictor of support for Donald Trump in 2016, in 
what clearly revels the effects of law and order and authoritarianism on the support for such political options.

\section{Democracy}

Mudde (2019: 7) clearly distinguish between extreme right parties and radical right formations, both belonging to the far-right category. Thus, whereas the "extreme right rejects the essence of democracy" the "radical right accepts the essence of democracy, but opposes fundamental elements of liberal democracy, most notably minority rights, rule of law and separation of powers".

Even if PRRPs are not anti-democratic, we cannot forget that some of these parties have their roots in to authoritarian movements, as is the case of the National Front or the FPÖ (Biorcio, 2003: 7). Although recent studies, (see Rovira Kaltwasser and van Hauwaert, 2020) do not find any relationship between populist attitudes and democratic support, others observe the opposed effect, i.e., a positive effect of the negative attitudes toward democracies on the vote for the PRRPs. For instance, this is the case of Spain, in which the likelihood to cast a vote for VOX instead of other political options increases for those more unsatisfied with democracy and those that considers that live in a democracy is not essential (Rama et al., 2021).

\section{Jair Bolsonaro and the rise of the Brazilian populist radical right}

The question now is, to what extent the existing literature can explain the vote for the PRR in Latin America. More in detail, we are interested in exploring whether the individual factors that explain the support for PRRPs in Western Europe and Bolsonaro are the same. In this sense, let us, fist, understand the context of the last elections in Brazil.

The results of the 2018 presidential elections meant a complete transformation in the dynamics of competition within the Brazilian party system and a breakdown on the traditional alignments between parties and voters. The presidential victory of Jair Bolsonaro, who headed a coalition of two small right-wing parties, the Social Liberal Party (PSL) and the Brazilian Labor Renewal Party (PRTB), has disrupted the pattern of political competition that had structured the system for more than two decades generating the condition for the populist radical right came to power for the first time in the country since the return to democracy (Zanotti and Roberts, 2021). 
On the one hand, with the election of Bolsonaro in 2018 the polarization between the Workers' Party (PT) and the Brazilian Social Democratic Party (PSDB) - that structured the system since the return to democracy_came to an end (Santos and Tanscheit, 2019). On the other hand, it resulted in a significant loss of representation in the National Congress for the PT, the PSDB and the Brazilian Democratic Movement (MDB), the three real existing parties in the last three decades in Brazil (Singer, 2018). Although losing votes and congressmen, the PT reached the second round of the presidential elections and remained the largest party in the Chamber of Deputies and, as the leader of the left.

Several events led to these changes. The more relevant was the impeachment of PT's former President Dilma Rousseff's in 2016, the participation of the two main right-wing parties, the PSDB and the MDB in the government of Michel Temer, who became the most unpopular president in the country's history. Also, there was the arrest of Luiz Inácio Lula da Silva, former president of Brazil from the PT, who was also barred from the election being the favorite contender until then. Last but not least, the massive corruption scandal known as Lava Jato (Car Wash Operation) and a prolonged economic crisis were, as well, relevant political events. As Santos and Tanscheit (2019) pointed out these events resulted in the collapse of the traditional and more moderate right-wing, which was replaced by a populist radical right led by Jair Bolsonaro. Indeed, the PSL not only won the presidential race, but elected the second largest parliamentary group, replacing the PSDB as the main party of the right in the country. In the following pages we want to address the main reason behind the vote for Bolsonaro, namely, i) negative political identities and the antiestablishment attitudes (Sameuls and Zucco, 2018; Zanotti and Roberts, 2021); ii) the politicization of massive corruption scandals (Rennó, 2020); iii) conservative values, morality and the aversion towards minority groups (Santos and Tanscheit, 2019), and iv) the political participation of neopetencostal evangelical churches (Setzler, 2021).

\section{Negative and anti-establishment political identities}

Exploring the relationship between populism and negative identities, Meléndez and Rovira Kaltwasser (2017), have pointed out that populism can thrive only when a negative political identity exists. Negative identities are defined as the repulsion towards a certain political party (Samuels and Zucco, 2018; Meléndez, 2019). In addition to an antipartisan political identity, Meléndez and Rovira Kaltwasser propose 
the existence of an antiestablishment political identity described as "an emotional and rational repulsion toward every established political party in a given country" (2019: 529). In this sense, it is only when voters have negative feelings against all traditional parties and can transform this into a new political identity that there is room for the emergence of an anti-system populist forces. The emergence of Bolsonaro in the forefront of the PSL fits well under this explanation, as the strong aversion toward the voters of the Workers' Party (the so-called antipetismo) was channelized by an antisystem leader. Not in vain, for the case of Brazil, an extensive literature showed that the PT in the last decades had a central role in structuring the party system by itself capturing both, high levels of positive but mostly negative identification with voters: the so-called petismo and antipetismo (Samuels and Zucco, 2018).

At the time of its foundation, PT supporters were found in all social classes. However, since 2002, there has been a decline among the most educated and wealthy sectors.Conversely, it is among the wealthy that antipetismo is highest (Samuels and Zucco, 2018).

With respect to the role of anti-establishment attitudes, Brazilian voters express the lowest (together with El Salvador and Peru) level of confidence in political parties compared to any other country in Latin America, to the point that, only 6 per cent expressed trust. ${ }^{6}$ This is partially consequence of the fact that the antipetista voter historically did not positively identify with other political parties in the system. Few antipetistas were sympathetic to the PSDB and no other party had benefited from high levels of antipetismo, since detesting one party does not mean liking another (Samuels and Zucco, 2018). Things changed only in the presidential elections of 2018, when antipetismo was linked to antiestablishment as a political identity. As Fuks et al. (2021) show, it is not only a case of antipetismo, but a rejection of the major parties of the country: disaffection with two or more parties jumped from $9,9 \%$ in 2002 to $29,2 \%$ in 2019. In other words, no political actor could profit from high levels of both antipetist and antiestablishment sentiments in the country. Conversely, Bolsonaro took advantage of this identity and achieved to incarnate both the antipetismo and antiestablishment vote (Fuks et al. 2021). In 2018, he declared at a rally that he would have shot petistas and send them to the edge of the beach, in reference to an old spawning ground for those murdered by the military dictatorship. However, to articulate both negative

\footnotetext{
${ }^{6}$ See the 2018 Latinobarómetro: https://www.latinobarometro.org/lat.jsp
} 
political identities, Bolsonaro had to politicize ongoing corruption scandals in the country.

\section{The politicization of massive corruption scandals}

If corruption has always been an issue in Brazil (Corporación Latinobarómetro, 2018), it is only with the massive corruption scandal known as Lava Jato that it became a major political issue (see Zanotti and Tanscheit, 2019), with an effect on vote choice. It is worth noting that this scandal was not the first in the recent history of the country. Indeed, in 2005 another scandal — the Mensalão — burst, when the deputy Roberto Jefferson accused the federal government, led by the PT, of buying votes in the Parliament in exchange for votes. The trial began in 2012, and the PT was the main party affected, with the detention of Lula's Minister of the Civil House of Lula, José Dirceu, and the president and treasurer of PT, José Genoíno and Delúbio Soares. However, the Mensalão does not affect the PT's electoral performance at that time mainly due to the good economic performance of the country (Hunter and Power, 2019). In 2006 Lula was re-elected and in 2010 he not only elected his successor, Dilma Rousseff, as he left the presidency with a record $97 \%$ popularity. ${ }^{7}$ It is worth noting that massive corruption scandals are functional to the populist discourse since for populist it is easier to depict the mainstream political establishment as a whole as corrupt, both morally and financially. This strategy of blame attribution has more chances to be successful when corruption bursts and the scandal affects the majority of the political class (Zanotti, 2019). When people are dissatisfied with the entire political class, voters are attracted to political options that present themselves as outsiders, helping populists to depict themselves as different from the corrupt, compromised and self-interested elite (Morgan, 2013). Indeed, Bolsonaro was able to present himself as an outsider and, therefore, "pure", disconnected from the old and corrupt elite. In highly disaffected society massive scandals tend to fuel antiestablishment vote. This is the case of Brazil, Lava Jato was decisive in enhancing both anti-establishmen and anti-PT sentiments.

\footnotetext{
${ }^{7}$ See "Popularidade de Lula bate recorde". Available in: http://g1.globo.com/politica/noticia/2010/12/popularidade-de-lula-bate-recorde-e-chega-87-dizibope.html. Access on 06/14/2019.
} 


\section{Nativism and authoritarianism in Bolsonaro's discourse}

When we compare voters of the PRR in Western Europe and Brazil we need to take into account the different contexts we are dealing with, especially concerning sociodemographic factors. This is particularly important with regard to nativism, the core ideology of the PRR, since in Brazil immigration is not a relevant issue. Defining nativism as a mix of nationalism and xenophobia (Mudde, 2007), in Brazil the phenomenon needs to be observed in the light of an ideal of nation raised by Bolsonaro and notably averse to the constitutional protection of minority groups mainly conceived in racial terms. Previous research has pointed out that Bolsonaro's supporters are more likely to be men, white and with high levels of income and education - among the middle and upper classes (Layton et al, 2021).

On the ideological point of view, Rennó (2020) shows that the 2018 Brazilian elections were marked by a "positional issue voting", in which Bolsonaro's electoral manifesto matched policy preferences of his voters. The typical Bolsonaro's voter rejects the PT but is also "oriented on an alignment of right-wing ideological positions unknown in recent Brazilian history" (Rennó, 2020: 5). Furthermore, his constituency is predominantly conservative, opposed to affirmative action policies based on racial quotas, abortion rights, and gun ownership.

While the conservatism in moral issue is not a defining attribute of the PRR, there are PRRPs that express their ideological authoritarianism through support for morally conservative policies. Authoritarianism is defined as "the belief in a strictly ordered society" (Mudde, 2007). In Western Europe PRRPs tend to express authoritarianism though a preference for stricter "law and order" policies (Mudde and Rovira Kaltwasser, 2017). However, some parties in the region such as VOX in Spain also express authoritarianism in a cultural sense (Rama et al. 2021).

The 2018 elections were marked by issues related to the expansion or suppression of the rights of minority groups, being Bolsonaro an opposer. The presidential campaign was marked by the slogan \#NotHim, which represented a movement led by women who carried out a series of mobilizations around Brazil against Bolsonaro. The demonstrations took place on-line and off-line and related to the misogynistic, racist and homophobic statements made by the then candidate.

Just to give a few examples of his attitude towards women, Bolsonaro told Congresswoman Maria do Rosário that he would not rape her because she "would not 
deserve it". ${ }^{8}$ On another occasion he mentioned that he fist had four sons and then a daughter out of a moment of weakness. ${ }^{9}$ Regarding to black people, following a visit to a settlement of African slave descendants called a quilombo, Bolsonaro suggested they were all overweight and said: "They don't do anything. They're no use even to procreate". ${ }^{10}$

With respect the racist component, studying the articulation of the PRR in Brazil under Bolsonaro provides new insights on the manner in which PRR leaders articulate both the nativist and authoritarian discourse and, at the same time, can shed more light on the determinants on the vote for these political options. In fact, since racism denies fundamental equality between all members of a society (Mudde, 2005) it goes hand in hand with the ideological authoritarianism of the PRR. Moreover, Bolsonaro uses racism to define "us" and to "them", respectively whites and non-whites. This is relevant also because there is not a great amount of research on the relationship between race and political behavior in Brazil.

Finally, Bolsonaro expresses its opinion also toward the LGBIT+ community, claiming that he would rather die in a car accident than have a homosexual child. He mentioned that a " $90 \%$ of the boys adopted by a homosexual couple will be homosexual and male escort". ${ }^{11}$ In sum, Bolsonaro somehow embodies the growth of neoconservatism and its attempts to prevent access to equal rights especially for women and LGBTI + through the use of "family values".

\section{Religion and support for Bolsonaro}

"Brazil above everything, God above everyone" was the slogan of Bolsonaro's presidential campaign. In fact, there are two main issues to which his campaign was build. First, the constant reference to the military dictatorship, which rhetorically used nationalism extensively during the period in power. Second, the reference to God with the objective of mobilizing Christians, the country's largest religion and the one with the strongest social and political linkages. These two issues are somehow entrenched in the history of Brazil. It is worth remembering the mobilizations pro-dictatorship in 1964 named the March of the Family with God for Freedom and during the same period the

\footnotetext{
${ }^{8}$ See: https://www.theguardian.com/world/2018/dec/23/maria-do-rosario-jair-bolsonaro-brazil-rape

${ }^{9}$ See: https://apnews.com/article/1f9b79df9b1d4f14aeb1694f0dc13276

${ }^{10}$ See: https://www.france24.com/en/20190508-racism-rare-brazil-says-far-right-bolsonaro

${ }^{11}$ See: https://www.nytimes.com/2019/07/20/world/americas/brazil-bolsonaro-greenwald.html
} 
campaign "Brazil, Love or Leave it". In Bolsonaro's discourse the politicization of the national feeling goes in hand with authoritarianism and the nostalgia of the military dictatorship. The President has expressed on different occasions on the dictatorial period saying that "it is not very different from what we have today" 12 and appraising dictatorship "a very good period" during the electoral campaign. ${ }^{13}$ Furthermore, on the occasion of the vote for the impeachment for former president Dilma Rousseff, Bolsonaro not only voted in favor, but declared: "they lost in 1964, they will lose now in 2016, for the family (...) for the memory of Colonel Carlos Alberto Brilhante Ustra (...) for the Armed Forces, for a Brazil above all and for God above all, my vote is yes". As Samuels and Zucco (2018) demonstrate, if Brazilians who see democracy as a value are more likely to be PT members, the anti-petistas are the less satisfied and those who show lower levels to support for democracy. In contrast, no one had achieved to attract those Brazilians with low support for democracy. Until 2014 anti-petistas only shared the rejection toward the PT without feeling close to any other party in the system.

In regard to traditional morality values, Bolsonaro stressed two popular themes, the idea of "gender ideology" and "non-partisan education". These views found allies in religious groups promoting censorship and mobilizing against, for example the teaching of sexuality in schools. This argument is relevant in Bolsonaro's discourse as it attacks feminism and the detractors of the heteronormative family. This is crucial if we take into account Bolsonaro's high popularity among of the evangelical electorate. In this context, the nomination of Pentecostal Evangelical pastor Damares Alves for the recently renamed Ministry of Women, Family and Human Rights ${ }^{14}$ does not come as a surprise.

\footnotetext{
${ }^{12}$ See: https://www1.folha.uol.com.br/internacional/en/brazil/2021/02/bolsonaro-praises-the-militaryand-says-that-brazil-under-the-dictatorship-was-not-too-different-from-today.shtml

${ }^{13}$ See: https://www.npr.org/2018/07/30/631952886/dictatorship-was-a-very-good-period-says-brazil-saspiring-president

${ }^{14}$ First, instituted in 1997, Human Rights Secretary was unified with the secretariats of Policies for the Promotion of Racial Equality and Policies for Women by President Dilma Rousseff in 2015, forming the Ministry of Women, Racial Equality and Human Rights. In 2016 it was extinguished by Michel Temer and recreated as a ministry in 2017 under the name of the Ministry of Human Rights. In the Bolsonaro government, the portfolio was transformed into the Ministry of Women, Family and Human Rights.
} 


\section{Expectations}

After having revised the most relevant explanations at the individual level to understand PRRP's support in Western Europe and for the specific case of Jair Bolsonaro in Brazil, we formulate the following expectations:

\section{Sociodemographics}

Expectation 1 (E1): We expect that man, younger individuals and those with low levels of education exhibit a higher probability to vote for a PRRP in Western Europe.

With respect to those who vote for Bolsonaro we expect them to be more likely men, with high levels of income and education - among the middle and upper classes.

\section{Economy}

E2: We expect that those unemployed to be more likely to cast a ballot for the PRRP in Western Europe than to another political option. In this sense, the negative evaluations of the economy help, as well, to understand the support for this set of parties. For the case of Bolsonaro, we do not expect neither unemployment, nor perceptions of the economic situation to play a role.

\section{Immigration and nativism}

E3: As has been stated on several occasions, negative attitudes towards immigrants boosted the vote for PRRPs in Western Europe. Being nativism one the defining ideologies of the PRR we expect that anti-immigrant sentiments also explain the vote for Bolsonaro.

\section{Law and Order and authoritarianism}

E4: In Western Europe ideological authoritarianism expressed through the support for law and order is a determinant for the vote for the PRRPs. As a consequence, we expect support for more strict law and order policies to be a determinant also of the vote for Bolsonaro.

\section{Democracy}

E5: We do not expect that those voters are less supportive of democracy show a higher propensity to vote for PRRPs in Western Europe. However, giving its authoritarianist messages, Bolsonaro's voters could attract those less attached to democracy. 
Finally, and regarding specific factors to understand Bolsonaro's support, as most of the previous studies have pointed out (Setzler, 2021; Layton et al., 2021), we expect that race (the withes), belonging to the Evangelist religious confession, those more critic with corruption scandals and, above all, those with the highest anti-PT feelings are more likely to cast a vote for Bolsonaro.

\section{Data and methods}

In order to carry out the analysis, we use survey data from the European Election Studies (EES-2019) for the European parties while we use the Estudio Electoral Brasileño (ESEB) for Bolsonaro. We rely on five different dependent variables: vote recall to four well-known European PRRPs: the German AfD, the Austrian FPÖ, the Italian Lega and the French RN, as well as the vote recall for the PRR candidate, Jair Bolsonaro in the 2018 Brazil elections. So, these five dependent variables are binary, coded 1 for having voted for a PRR option and 0 for casting a ballot for another political option (abstainers, those who do not know whether they voted or not, and those not answering the question, are omitted from the analysis).

With regard to our variables at the individual level, we mainly focus on two different blocks: sociodemographic and political and economic variables. Regarding the first one, we insert sex ( $1=$ female; $0=$ male), age (in categories: 18-24, 25-39, 40-54, 55-64, +65), education level $(1=$ lower; $2=$ medium; and $3=$ high $)$, and work situation ( $0=$ employed; 1=unemployed). The political block contains six variables: positive economic sociotropic evaluation ( 1 =better economic situation; $0=$ worse economic situation), leftright scale ( $0=$ left; $10=$ right), satisfaction with democracy $(0=$ satisfied; $10=$ unsatisfied), Law and order (a coercive attitude goes against civil rights: $1=$ strongly agree; $2=$ agree; $3=$ neither agree not disagree; $4=$ disagree; $5=$ strongly disagree); Essential to live in democracy $(1=$ a democratic political system is preferable; $0=$ the political system is indifferent or sometimes an authoritarian regime is preferable), Immigration positive $(0=$ people from other countries make the country worse; $10=$ immigrants make the country a better place to live).

We introduce simultaneously these variables in our statistical models. This is possible, as the VIFs (variance inflation factors) of all variables are well below the levels that would rise concerns of collinearity problems: for the logistic regression with AfD the 
mean VIF is 1.04 (highest VIF belongs to satisfaction with democracy $=1.11$ ); for FPÖ is 1.06 (highest VIF belongs to positive economic sociotropic evaluation $=1.13$ ) for Lega is 1.07 (highest VIF belongs to left-right scale $=1.20$ ); for NR is 1.08 (highest VIF belongs to positive economic sociotropic evaluation $=1.18$ ), and for Bolsonaro is 1.08 (highest VIF belongs to Educational level=1.32). See Table A1 in the Appendix with the descriptive variables and the VIFs reported for each one of the variables.

\section{Results}

Table A2 in the Online Appendix report the coefficients and levels of statistical significance for each one of the independent variables considered in our analysis. However, one limitation of these logistic regression coefficients is that they do not provide us with information regarding the comparative magnitude of each covariate's effect. Therefore, we calculated their average marginal effects (AMEs), which capture the average changes in the probability of vote for the five populist radical right parties (and leader) - e.g., AfD, FPÖ, Lega, RN and the candidate Jair Bolsonaro - instead of other political options. The AMEs are calculated as follows: for each observation of the dataset, the marginal effect of a given variable (holding all other independent variables constant) on our dependent variable is estimated, and then these estimations are averaged for all the observations. All of the independent variables ranged from 0 to 1 . The AMEs for the probability of support the populist radical right forces are displayed in Figure 1and Figure 2

For the interpretation of the figures 1 and 2, we have to bear in mind that each horizontal line represents an independent variable of the model, the point standing for the best estimation of its effect upon the dependent variable, and the line, for its $95 \%$ confidence interval. If a confidence interval crosses the vertical line drawn at the origin (zero) of the horizontal axis (representing the absence of effects), the effect of the variable is not statistically significant. If it does not and is located to its right, the effect is positive and statistically significant, whereas if it is located to its left, the effect is negative and statistically significant. 


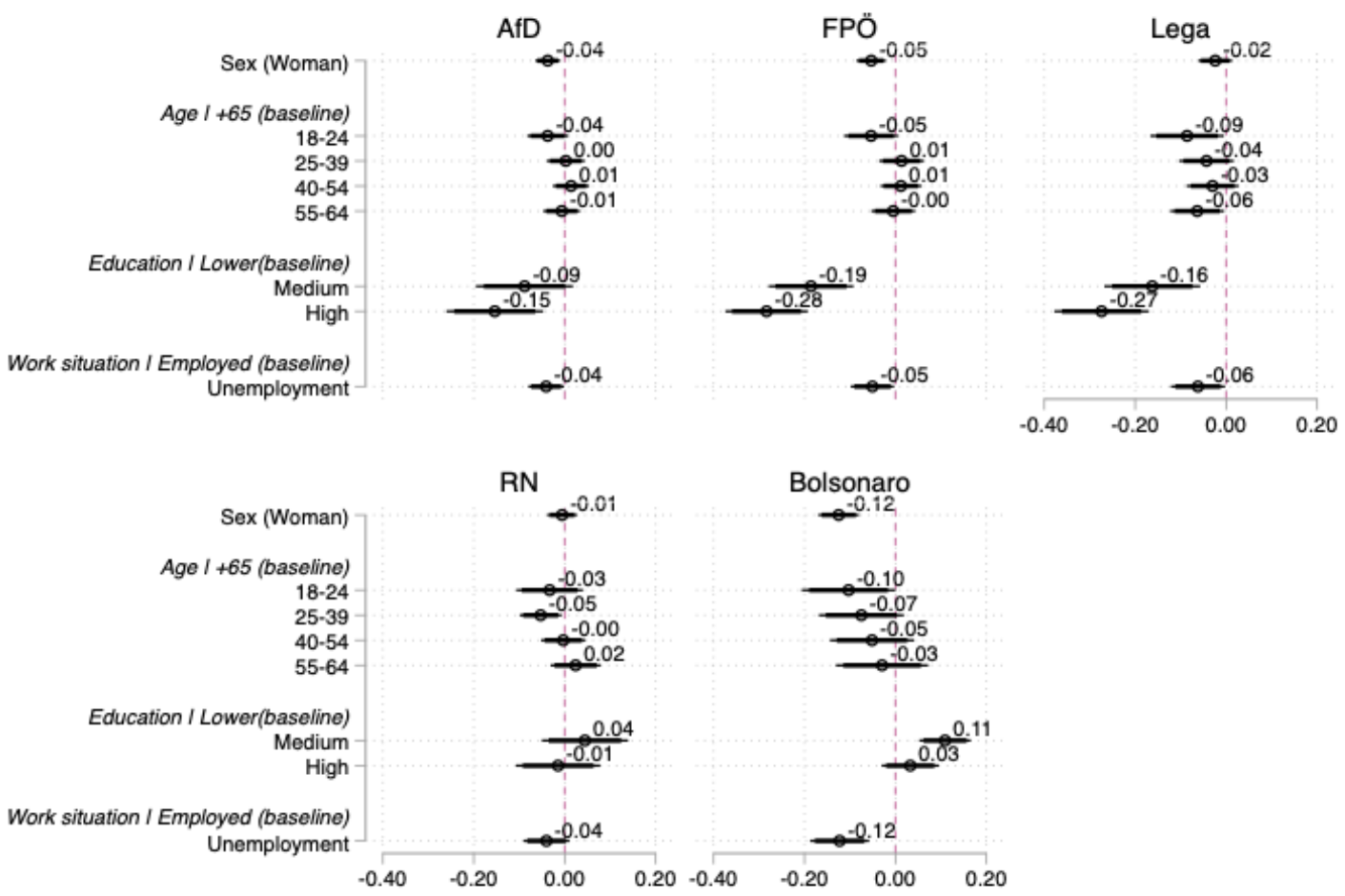

Figure 1. AMEs for the sociodemographic factors to explain the support for PRRPs in Europe and Bolsonaro in Brazil

Source: Elaboration of the authors based on EES 2019 and ESEB 2018.

Figure 1 shows that, women are less likely to support Bolsonaro (12 per cent less able to do that) - we do not find this gender gap for FPÖ, Lega or RN -, he finds support among medium educated voters (they are in an 11 per cent points more able to vote for Bolsonaro compared with lower educated voters) and those unemployed are as well less able to cast a vote for Bolsonaro. Thus, the main differences among Bolsonaro and the other four PRRPs is regarding these three variables. As we expect (see E1) age is not a significant determinant of the vote for Bolsonaro (in fact it just goes in the expected direction for FPÖ), and the most relevant finding is with regard education as those with secondary level of education exhibit a higher likelihood to cast a vote to Bolsonaro, being the most solid sociodemographic variable to explain the vote for the rest of the PRRPs, as it is statistically significant for AfD, FPÖ and Lega, being the lower educated the more prone to support these parties.

On the other hand, Figure 2 shows important differences among Bolsonaro electoral bases and the other four Western European PRRP's supporters. Thus, with regard to sociotropic considerations of countries' economic situation, those who vote for Bolsonaro are the ones with positive evaluation (something that just goes in line with findings for the FPÖ). For the RN and AfD as we expected, the coefficient is negative 
(statistically significant for the case of RN). Regarding ideology, although it is thin (Stanley 2008) is statistically significant for all of the five cases and exhibit a higher coefficient level. However, the higher effect of this variable belongs to FPÖ and Lega: 43 per cent and 48 per cent of the probabilities to vote for these parties, respectively, among those that place themselves more on the right side of left-right axis. The likelihood to vote for Bolsonaro among the rightist is the 37 per cent. Regarding satisfaction with democracy, we just find the expected direction for AfD and RN, being not statistically significant for FPÖ and Bolsonaro. With regard to our measure of law and order, that captures the "authoritarian" nature of this political options, we find the expected direction for FPÖ, Lega and Bolsonaro. One of the most relevant findings in this section is the one regarding the variable Essential to live in a democracy, whereas it is not statistically significant for AfD, FPÖ and NR, it is for Lega and Bolsonaro, to the point that the likelihood to vote for the Brazilian President decrease of 18 per cent for those that consider living in a democracy is relevant. Importantly enough, the factor that commonly was described as the main driver of PRRPs support, attitudes towards immigrant population, goes in the expected direction for Lega and RN (with a higher AME), being not statistically significant in order to understand Bolsonaro's support.
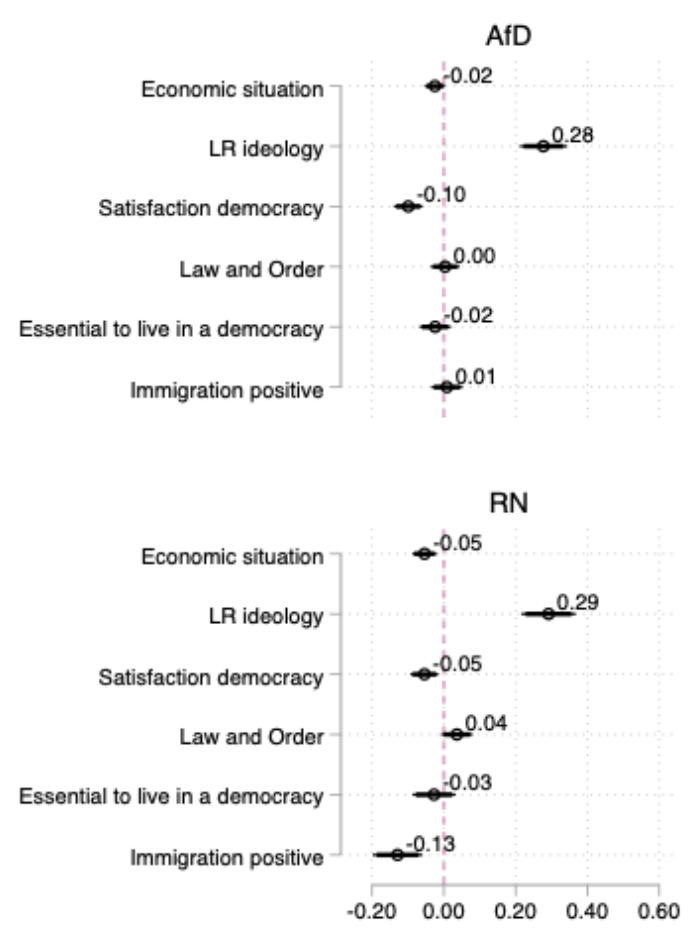

Figure 2. AMEs for the political, cultural and economic factors to explain the support for PRRPs in Europe and Bolsonaro in Brazil

Source: Elaboration of the authors based on EES 2019 and ESEB 2018. 
To sum up, and regarding the political and economic factors that explains the vote for Bolsonaro, we reject the material deprivation thesis, the one focused on immigration, and the arguments that poses that those more unsatisfied with the way democracy works are the most able to cast a vote for these fringe options, do not goes in the expected direction to explain the vote for Bolsonaro. Finally, and although studies such as the one of Rovira Kaltwasser and van Hauwaert (2020) although focused on the populist voters, do not find evidence about that they are more able to be in favour to non-democratic political systems, it seems to explain Bolsonaro's success.

\section{Disentangling Bolsonaro support}

Following the specific expectations to understand the electoral support to Bolsonaro, in Figure 3 (see also Table A3 in the Appendix) we maintain the variables included in both, Figure 1 and 2, adding specific variables that captures income levels (continuous variable from the lowest to the highest value of monthly income); race (1=black; $2=$ brown; $3=$ white; $4=$ yellow; $5=$ Indian), religious confession $(1=$ catholic; $2=$ Evangelist; $3=$ other or non-religious $)$, corruption is generalized in Brazil $(1=$ very generalized; $2=$ well generalized; $3=$ little generalized; $4=$ it hardly happens); inequality as one of the major problems in Brazil ( $1=\mathrm{yes})$, anti-PT sentiments $(0=$ lower probabilities to cast a vote for PT; 10=higher probabilities to cast a vote for PT). Figure 3, divided in four columns, distinguish between a dependent variable building following the same way that the one presented in Figures 1 and 2 (vote recall to Bolsonaro vs other political options) - see first and second column - and an additional dependent variable that compares Bolsonaro's electoral bases (1) with the ones that voted for Haddad, the leader of the biggest, former political party in Brazil: PT (codified as 0). Furthermore, and given the relevance of this variable (Samuels and Zucco 2018), in the pair columns (2 and 4) we introduce the Anti-PT sentiment. The results are clear, focusing on the two first columns we find that, even controlling for anti-PT sentiments, race (white) and religious denomination (Evangelist) matters to understand the vote to Bolsonaro instead other political candidate. However, both, income levels and the perception of corruption in Brazil just raise the statistical significance levels and with the expected sign (direction) in the first model (without anti-PT sentiments), being those with higher levels of income and the ones that perceives that corruption is generalized in Brazil, the ones with a higher likelihood to cast a vote for Bolsonaro. 
On the other hand, by trying to disentangle the factors that led a voter to support Bolsonaro instead of the candidate of PT, Haddad, we find that income, race and religion denomination (Evangelist) the three elements, gain on their relevance to explain Bolsonaro's vote (even in the fourth model that includes the anti-PT variable), at the time that the corruption factor lose their statistical significance when we control for the anti-PT variable. These findings clearly highlight that, on the opposite that WE PRRPs, the voter bases of Bolsonaro are a prototype of a rich white man of Evangelical religion, who emphasize the importance of law and order, against democracy as a political system, and with a clear anti-political sentiment, specifically against the party that has traditionally been in power for more years: the PT.

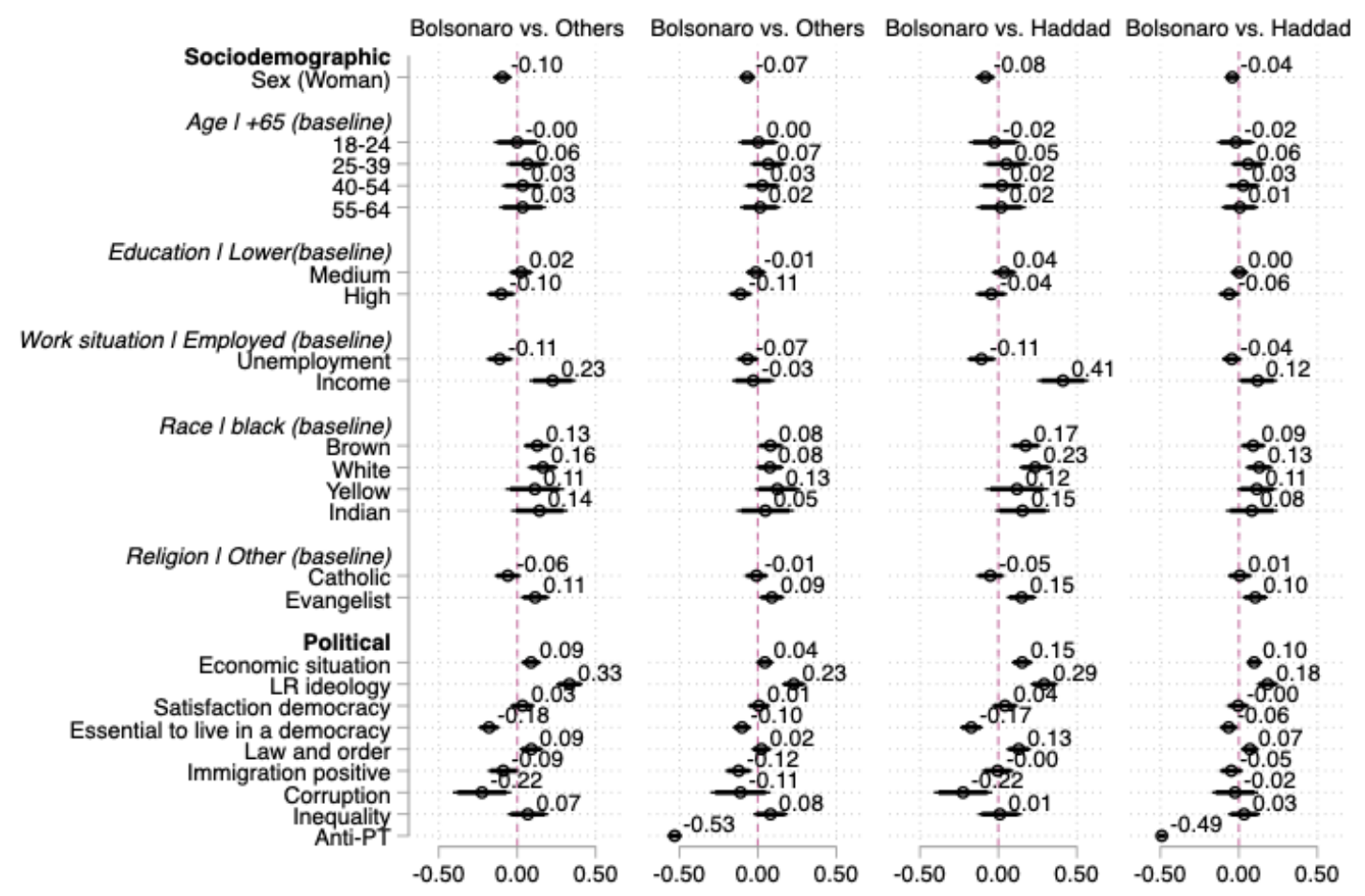

Figure 3. AMEs for the sociodemographic, political, economic, and attitudinal factors to explain the support for Bolsonaro in Brazil vs other political options and vs Haddad Source: Elaboration of the authors based on BES 2018.

Finally, Figure 4, that displays specific marginal effects for the most relevant variables to explain Bolsonaro's vote, i.e., race, religious denomination, income and antipetismo, shed additional light on the probabilities to support Bolsonaro, instead of other political options. The results are clear and reinforce the AMEs displayed in Figure 3, with those with high income, white, Evangelist and with lower attachments to the PT, being the most able to support the former Army Captain. 

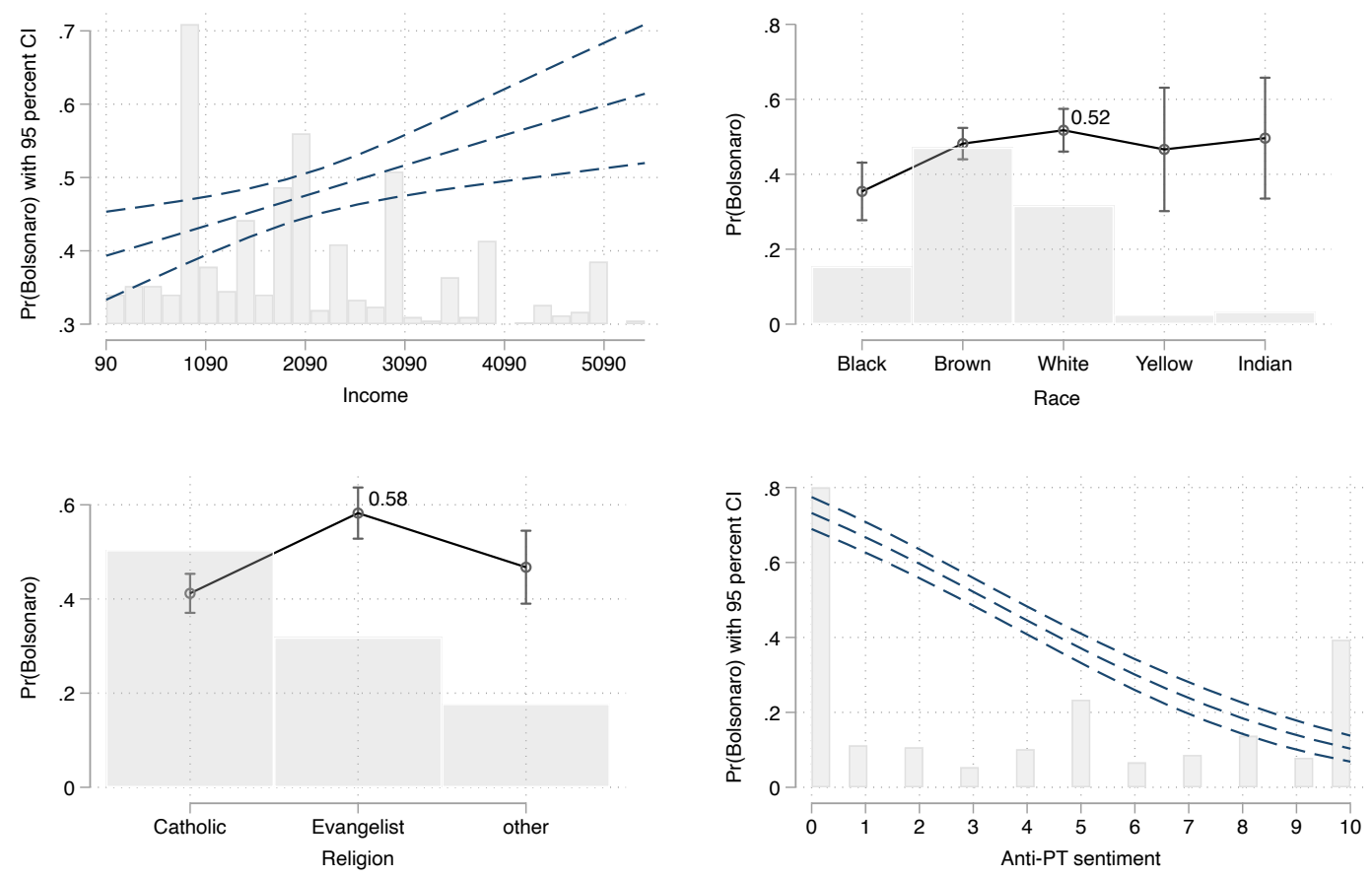

Figure 4. Marginal effects for the main independent variables to explain Bolsonaro's support

Source: Elaboration of the authors based on ESEB 2018.

\section{Conclusions}

The populist radical right is the most studied populist party family in the academia due their presence in many regions of the world. However, most of these studies have focused on Europe (especially in Western Europe) and, later, the United States mainly after the election of Donald Trump as President.

Even if Latin America has been historically one of the regions where populism has had more success, until now, it has not been a fertile soil for the populist radical right. The exception is Jair Bolsonaro in Brazil that surprisingly achieved the presidency in the 2018 election. Lately much has been written on the rise of Bolsonaro and the profile of its voters. However, we believe that following Mudde (2016), in order to broaden the knowledge, we have on the support for the radical right, we need to make a comparative effort. In line with this we compare the determinants of the vote for Bolsonaro with those of four populist radical right parties in Western Europe: The League in Italy, AfD in Germany, the Austrian FPÖ and the French Resemblement National (former Front National).

We found that Bolsonaro's voters are high-income white males evangelical with an intermediate education, and of intermediate education levels. Furthermore, as previous research has underlined his voters display high levels of despise for established parties, 
mainly the Worker's Party (PT). Interestingly enough, and given the relevance of traditionalism in Bolsonaro's discourse, those in favour to the law-and-order doctrine, ideological placed on the right side and with anti-democratic feelings were more likely to vote for Bolsonaro.

All in all, this article shed some light on one of the future cases of study in the field: the (populist) radical right in Latin America, by underlining that anti-elite sentiments, the authoritarian feelings, and the levels of income, race and the religious denomination, are relevant factors to explain radical-right support.

\section{References}

Arzheimer K (2018). Explaining Electoral Support for the Radical Right. In Rydgren J (ed.), The Oxford Handbook of the Radical Right. New York: Oxford University Press, pp. 143-165.

Bartolini, S., and Mair, P. (1990). Identity, Competition, and Electoral Availability: The Stabilization of European Electorates 1885-1985. Cambridge: Cambridge University Press.

Berbuir, N., Lewandowsky, M., and Siri, J. (2015). The AfD and its sympathisers: Finally a right-wing populist movement in Germany?. German Politics, 24(2), 154178.

Betz, H. G. (1994). Radical Right-Wing Populism in Western Europe. Springer.

Biorcio, R. (2003). Italian populism: from protest to governing party, paper presented at the Conference of the European Consortium for Political Research, Marburg 18-21 September.

Dalton, R. J., and Weldon, S.A. (2005). Public Images of Political Parties: A Necessary Evil? West European Politics 28(5): 931-951.

Dalio, R., S. Kryger, J. Rogers and D. Gardner. (2017). Populism: The phenomenon. Bridgewater: Daily Observations, 203 (226-3030)

de la Torre, C. and Arnson, C. (2013). Latin American Populism in the Twenty-Fist century. Baltimore and Washington DC, Johns Hopkins University Press.

Donovan, T. (2019). Authoritarian attitudes and support for radical right populists, Journal of Elections, Public Opinion and Parties, 29:4, 448-464, DOI: 10.1080/17457289.2019.1666270 
Eatwell, R., and Goodwin, M. (2018). National populism: the revolt against liberal democracy, Penguin Random House.

Fuks, M., Ribeiro, E., and Borba, J. (2021). From Antipetismo to Generalized Antipartisanship: The Impact of Rejection of Political Parties on the 2018 Vote for Bolsonaro. Brazilian Political Science Review, 15(1), e0005. https://doi.org/10.1590/1981-3821202100010003

Franklin, M., T. Mackie, and H. Valen. (1992). Electoral Change. Responses to envolving social and attitudinal structures in Western countries. Cambridge University Press: New York

Funke, M., M. Schularick, and C. Trebesch. (2016). Going to extremes: Politics after financial crisis, 1870-2014. European Economic Review 88 (C): 227-260.

Hawkins, K. A. and Rovira-Kaltwasser, C. (2019) Introduction: The ideational approach, in Hawkins, K. A. et al. (eds) The Ideational Approach to Populism: Concept, Theory, and Analysis. New York: Routledge.

Hernández, E., and H. Kriesi. (2016). The Electoral Consequences of the Financial and Economic Crisis in Europe. European Journal of Political Research 55(2): 203224.

Hunter, W., and Power, T. J. (2019). Bolsonaro and Brazil's illiberal backlash. Journal of Democracy, 30(1), 68-82.

Ignazi, P. (2017). Party and Democracy: The Uneven Road to Party Legitimacy, Oxford: Oxford University Press.

Ivarsflaten, E. (2008). What Unites the Populist Right in Western Europe? Reexamining grievance mobilization models in seven successful cases. Comparative Political Studies, 41 (1): 3-23.

Katz, R.S., and Mair, P. (1995). Changing Models of Party Organization and Party Democracy. The emergence of the Cartel Party. Party Politics 1(1): 5-28.

Kaufmann, E. (2017). Levels or changes?: Ethnic context, immigration and the UK Independence Party vote. Electoral Studies, 48, 57-69.

Laclau, E. 2005. On populist Reason. London: Verso Books.

Layton, M, Erica Smith, A. Moseley, M.W. and Cohen, M.J. (2021). Demographic polarization and the rise of the far right: Brazil's 2018 presidential election, Research \& Politics, Doi: https://doi.org/10.1177/2053168021990204 
Lipset, S. M., and S. Rokkan. (1967). Party Systems and voter alignments: Cross national perspectives. New York: Free Press.

Lubbers M., Gisberts M., and Scheepers P. (2002). Extreme Right-Wing Voting in Western Europe. European Journal of Political Research 41(3), 345-378.

Madrid, R. (2012). The Rise of Ethinic Politis in Latin America. Cambridge: Cambrindge University Press

Meléndez, C. (2019). El mal menor: Vínculos políticos en el Perú posterior al colapso del sistema de partidos. Instituto de Estudios Peruanos.

Meléndez, C., and Rovira Kaltwasser, C. (2019). Political identities: The missing link in the study of populism. Party Politics, 25(4), 520-533.

Mendes, M.S., and Dennison, J. (2020). Explaining the emergence of the radical right in Spain and Portugal: salience, stigma and supply. West European Politics, Online First: 10.1080/01402382.2020.1777504.

Morgan, J. (2013). Bankrupt representation and party system collapse. University Park: Penn State University Press

Mols, F., and Jetten, J. (2016). Explaining the Appeal of Populist Right-Wing Parties in Times of Economic Prosperity. Political Psychology 37 (2): 275-292.

Mudde, C. (2005). Racist Extremism in Central \& Eastern Europe. Routledge.

Mudde, C. (2007). Populist Radical Right Parties in Europe. Cambridge: Cambridge University Press.

Mudde, C. (2017). The study of populist radical right parties: towards a fourth wave. CRex Working Paper Series 1/2016.

Mudde, C. (2019). The Far Right Today. Cambridge: Polity Press.

Mudde, C., and Rovira Kaltwasser, R. (eds.) (2012). Populism in Europe and the Americas: Threat or Corrective for Democracy? Cambridge: Cambridge University Press

Mudde, C., and Rovira Kaltwasser, C. (2017). Populism. A very short introduction. Oxford: Oxford University Press.

Norris P and Inglehart R (2019). Cultural Backlash: Trump, Brexit, and Authoritarian Populism. New York: Cambridge University Press. 
Rama, J., Zanotti, L., Turnbull-Dugarte, S., and Santana, A. (2021). Vox: The Rise of the Spanish Populist Radical Right, Routledge: Extremism and Democracy

Rennó, L. (2020). The Bolsonaro Voter: Issue Positions and Vote Choice in the 2018 Brazilian Presidential Elections. Latin American Politics and Society, 62(4), 1-23. doi:10.1017/lap.2020.13

Rico, G., and Anduiza, E. (2019). Economic Correlates of Populist Attitudes: An Analysis of Nine European Countries in the Aftermath of the Great Recession. Acta Politica 54(3), 371-397.

Roberts, K. M. (2017). State of the Field: Party politics in hard times: Comparative perspectives on the European and Latin American economic crises. European Journal of Political Research, 56(2), 218-233.

Roberts, K.M. (2006). Populism, political conflict, and grass-roots organization in Latin America, Comparative Politics, 38(2): 127-148

Rooduijn, M., and Burgoon, B. (2017). The Paradox of Well-being: Do Unfavourable Socioeconomic and Sociocultural Contexts Deepen or Dampen Radical Left and Right Voting Among the Less Well-Off? Comparative Political Studies 51(13), $1720-1753$

Rooduijn, M. (2018). What Unites the Voter Bases of Populist Parties? Comparing the Electorates of 15 Populist Parties. European Political Science Review, 10(3):351368. doi:10.1017/S1755773917000145.

Rovira Kaltwasser, C. (2014). The Responses of Populism to Dahl's Democratic Dilemmas. Political Studies 62(3): 470-487.

Rovira Kaltwasser, C. and van Hauwaert, S.M. (2020). The populist citizen: Empirical evidence from Europe and Latin America, European Politics and Society, 12(1):118

Samuels, D. J., and Zucco, C. (2018). Partisans, antipartisans, and nonpartisans: voting behavior in Brazil. Cambridge: Cambridge University Press.

Santos, F., and Tanscheit, T. (2019). Quando velhos atores saem de cena: a ascensão da nova direita política no Brasil. Colombia Internacional, (99), 151-186.

Singer, A. (2018). O lulismo em crise: Um quebra-cabeça do período Dilma (20112016). São Paulo: Companhia das Letras.

Stanley, B. (2008). The Thin Ideology of Populism. Journal of Political Ideologies 13(1), 95-110. 
Setzler, M. (2021). Did Brazilians Vote for Jair Bolsonaro Because They Share his Most Controversial Views?. Brazilian Political Science Review, 15(1), e0002. https://doi.org/10.1590/1981-3821202100010006

Stockemer D, Lentz T and Mayer D. (2018). Individual Predictors of the Radical RightWing Vote in Europe: A Meta-Analysis of Articles in Peer-Reviewed Journals (1995-2016). Government and Opposition 53(1), 569-593.

van Biezen, I. (2004). Political Parties as Public Utilities. Party Politics, 10(6), 701722.

van Hauwaert SM and van Kessel S. (2018). Beyond Protest and Discontent: A CrossNational Analysis of the Effect of Populist Attitudes and Issue Positions on Populist Party Support. European Journal of Political Research 57, 68-92.

Weyland, K. 2001. "Clarifying a Contested Concept: Populism in the Study of Latin American Politics". Comparative Politics 34 (1): 1-22.

Zanotti L and Roberts KM (2021). (Aún) Una Excepción y no la Regla: La Derecha Populista Radical en América Latina. Revista Uruguaya de Ciencia Política. 
Online Appendix

Table A1. Description of variables

\begin{tabular}{|c|c|c|c|c|c|c|}
\hline Bolsonaro & $\mathbf{N}$ & Mean & Std. Dev. & Min & Max & VIF \\
\hline Gender (1=Female) & 2.506 & 0.5 & 0.5 & 0 & 1 & 1.07 \\
\hline Age & 2.483 & 2.7 & 1.2 & 1 & 5 & 1.18 \\
\hline Education & 2.506 & 1.8 & 0.8 & 1 & 3 & 1.32 \\
\hline Unemployed & 2.488 & 0.2 & 0.4 & 0 & 1 & 1.04 \\
\hline Income & 1.788 & 0.4 & 0.2 & 0.02 & 1 & 1.23 \\
\hline Race & 2.445 & 2.3 & 0.9 & 1 & 5 & 1.02 \\
\hline Religion & 2.506 & 1.7 & 0.8 & 1 & 3 & 1.03 \\
\hline Economic situation & 2.446 & 0.3 & 0.5 & 0 & 1 & 1.05 \\
\hline L-R ideology & 1.973 & 0.7 & 0.3 & 0 & 1 & 1.03 \\
\hline Satisfaction democracy & 2.440 & 0.2 & 0.4 & 0 & 1 & 1.06 \\
\hline Essential live democracy & 2.506 & 0.7 & 0.5 & 0 & 1 & 1.04 \\
\hline Law and order & 1.935 & 0.4 & 0.4 & 0 & 1 & 1.04 \\
\hline Immigration attitudes & 2.403 & 0.7 & 0.3 & 0.2 & 1 & 1.07 \\
\hline Corruption & 2.442 & 0.3 & 0.2 & 0.25 & 1 & 1.10 \\
\hline Inequality & 2.449 & 0.3 & 0.2 & 0.2 & 1 & 1.09 \\
\hline Anti-PT & 2.327 & 0.4 & 0.4 & 0 & 1 & 1.09 \\
\hline AfD & $\mathbf{N}$ & Mean & Std. Dev. & Min & Max & VIF \\
\hline Gender (1=Female) & 1.595 & 0.52 & 0.50 & 0 & 1 & 1.03 \\
\hline Age & 1.597 & 3.06 & 1.28 & 1 & 5 & 1.06 \\
\hline Education & 1.428 & 2.51 & 0.58 & 1 & 3 & 1.03 \\
\hline Unemployed & 1.597 & 0.06 & 0.24 & 0 & 1 & 1.02 \\
\hline Economic situation & 1.544 & 0.63 & 0.48 & 0 & 1 & 1.10 \\
\hline L-R ideology & 1.479 & 0.49 & 0.22 & 0 & 1 & 1.05 \\
\hline Satisfaction democracy & 1.579 & 0.39 & 0.49 & 0 & 1 & 1.11 \\
\hline Law and order & 1.535 & 0.48 & 0.34 & 0 & 1 & 1.03 \\
\hline Essential live democracy & 1.571 & 0.92 & 0.27 & 0 & 1 & 1.04 \\
\hline Immigration attitudes & 1.529 & 0.47 & 0.33 & 0 & 1 & 1.03 \\
\hline FPÖ & $\mathbf{N}$ & Mean & Std. Dev. & Min & Max & VIF \\
\hline Gender (1=Female) & 1.587 & 0.52 & 0.50 & 0 & 1 & 1.02 \\
\hline Age & 1.591 & 3.05 & 1.27 & 1 & 5 & 1.04 \\
\hline Education & 1.402 & 2.44 & 0.64 & 1 & 3 & 1.02 \\
\hline Unemployed & 1.591 & 0.06 & 0.24 & 0 & 1 & 1.02 \\
\hline Economic situation & 1.523 & 0.72 & 0.45 & 0 & 1 & 1.13 \\
\hline L-R ideology & 1.464 & 0.48 & 0.23 & 0 & 1 & 1.10 \\
\hline Satisfaction democracy & 1.578 & 0.41 & 0.49 & 0 & 1 & 1.12 \\
\hline Law and order & 1.537 & 0.46 & 0.33 & 0 & 1 & 1.05 \\
\hline Essential live democracy & 1.567 & 0.92 & 0.27 & 0 & 1 & 1.03 \\
\hline Immigration attitudes & 1.524 & 0.46 & 0.33 & 0 & 1 & 1.07 \\
\hline
\end{tabular}




\begin{tabular}{|c|c|c|c|c|c|c|}
\hline Lega & $\mathbf{N}$ & Mean & Std. Dev. & Min & Max & VIF \\
\hline Gender (1=Female) & 1.584 & 0.52 & 0.50 & 0 & 1 & 1.01 \\
\hline Age & 1.585 & 3.08 & 1.28 & 1 & 5 & 1.09 \\
\hline Education & 1.429 & 2.45 & 0.62 & 1 & 3 & 1.04 \\
\hline Unemployed & 1.585 & 0.08 & 0.27 & 0 & 1 & 1.03 \\
\hline Economic situation & 1.537 & 0.60 & 0.49 & 0 & 1 & 1.08 \\
\hline L-R ideology & 1.447 & 0.52 & 0.27 & 0 & 1 & 1.20 \\
\hline Satisfaction democracy & 1.570 & 0.32 & 0.47 & 0 & 1 & 1.08 \\
\hline Law and order & 1.530 & 0.52 & 0.35 & 0 & 1 & 1.04 \\
\hline Essential live democracy & 1.562 & 0.91 & 0.28 & 0 & 1 & 1.02 \\
\hline Immigration attitudes & 1.541 & 0.44 & 0.34 & 0 & 1 & 1.15 \\
\hline$R N$ & $\mathbf{N}$ & Mean & Std. Dev. & Min & $\operatorname{Max}$ & VIF \\
\hline Gender (1=Female) & 1.464 & 0.52 & 0.50 & 0 & 1 & 1.02 \\
\hline Age & 1.465 & 3.08 & 1.28 & 1 & 5 & 1.06 \\
\hline Education & 1.323 & 2.59 & 0.55 & 1 & 3 & 1.03 \\
\hline Unemployed & 1.465 & 0.07 & 0.26 & 0 & 1 & 1.02 \\
\hline Economic situation & 1.414 & 0.61 & 0.49 & 0 & 1 & 1.18 \\
\hline L-R ideology & 1.326 & 0.52 & 0.26 & 0 & 1 & 1.12 \\
\hline Satisfaction democracy & 1.448 & 0.33 & 0.47 & 0 & 1 & 1.17 \\
\hline Law and order & 1.402 & 0.50 & 0.34 & 0 & 1 & 1.06 \\
\hline Essential live democracy & 1.432 & 0.91 & 0.28 & 0 & 1 & 1.03 \\
\hline Immigration attitudes & 1.411 & 0.41 & 0.33 & 0 & 1 & 1.14 \\
\hline
\end{tabular}

Source: Elaboration of the authors based on EES 2019 and ESEB 2018. 
Table A2. Logistic regression voted for PRRPs and Bolsonaro instead other political options

\begin{tabular}{|c|c|c|c|c|c|}
\hline & AfD & FPÖ & Lega & NR & Bolsonaro \\
\hline Gender $(1=$ female $)$ & $\begin{array}{l}-0.46^{*} \\
(0.24)\end{array}$ & $\begin{array}{l}-0.29 \\
(0.22)\end{array}$ & $\begin{array}{c}0.06 \\
(0.18)\end{array}$ & $\begin{array}{c}0.06 \\
(0.23)\end{array}$ & $\begin{array}{c}-0.52 * * * \\
(0.13)\end{array}$ \\
\hline \multicolumn{6}{|l|}{ Age (baseline $=+65)$} \\
\hline $18-24$ & $\begin{array}{c}0.75 \\
(0.79)\end{array}$ & $\begin{array}{l}1.71 * \\
(0.92)\end{array}$ & $\begin{array}{c}0.18 \\
(0.49)\end{array}$ & $\begin{array}{l}-1.14^{*} \\
(0.63)\end{array}$ & $\begin{array}{c}0.25 \\
(0.19)\end{array}$ \\
\hline $25-39$ & $\begin{array}{c}1.04 \\
(0.79)\end{array}$ & $\begin{array}{l}1.77 * \\
(0.93)\end{array}$ & $\begin{array}{c}0.05 \\
(0.47)\end{array}$ & $\begin{array}{l}-0.57 \\
(0.58)\end{array}$ & $\begin{array}{c}0.22 \\
(0.19)\end{array}$ \\
\hline $40-54$ & $\begin{array}{c}0.55 \\
(0.81)\end{array}$ & $\begin{array}{l}1.68 * \\
(0.94)\end{array}$ & $\begin{array}{l}-0.12 \\
(0.49)\end{array}$ & $\begin{array}{l}-0.55 \\
(0.61)\end{array}$ & $\begin{array}{c}0.34 \\
(0.24)\end{array}$ \\
\hline $54-64$ & $\begin{array}{c}0.96 \\
(0.80)\end{array}$ & $\begin{array}{l}1.59^{*} \\
(0.93)\end{array}$ & $\begin{array}{c}0.56 \\
(0.48)\end{array}$ & $\begin{array}{l}-0.82 \\
(0.61)\end{array}$ & $\begin{array}{c}0.12 \\
(0.30)\end{array}$ \\
\hline \multicolumn{6}{|l|}{ Education $(1=$ low $)$} \\
\hline Medium & $\begin{array}{c}-0.77 * * \\
(0.37)\end{array}$ & $\begin{array}{c}-1.26 * * * \\
(0.29)\end{array}$ & $\begin{array}{l}-0.68^{*} \\
(0.35)\end{array}$ & $\begin{array}{c}0.70 \\
(0.77)\end{array}$ & $\begin{array}{c}0.51^{* * *} \\
(0.16)\end{array}$ \\
\hline High & $\begin{array}{c}-1.93 * * * \\
(0.40)\end{array}$ & $\begin{array}{c}-2.55 * * * \\
(0.32)\end{array}$ & $\begin{array}{c}-1.44 * * * \\
(0.36)\end{array}$ & $\begin{array}{l}-0.00 \\
(0.78)\end{array}$ & $\begin{array}{c}0.09 \\
(0.17)\end{array}$ \\
\hline Unemployed & $\begin{array}{l}-1.13 \\
(0.74)\end{array}$ & $\begin{array}{l}-0.58 \\
(0.50)\end{array}$ & $\begin{array}{l}-0.12 \\
(0.40)\end{array}$ & $\begin{array}{c}-1.30 * * \\
(0.51)\end{array}$ & $\begin{array}{c}-0.49 * * * \\
(0.19)\end{array}$ \\
\hline Economic situation & $\begin{array}{l}-0.42 * \\
(0.24)\end{array}$ & $\begin{array}{c}0.60 * * \\
(0.26)\end{array}$ & $\begin{array}{c}0.29 \\
(0.21)\end{array}$ & $\begin{array}{c}-0.78 * * * \\
(0.25)\end{array}$ & $\begin{array}{c}0.51 * * * \\
(0.13)\end{array}$ \\
\hline L-R ideology & $\begin{array}{c}4.62 * * * \\
(0.52)\end{array}$ & $\begin{array}{c}5.31 * * * \\
(0.51)\end{array}$ & $\begin{array}{c}4.83 * * * \\
(0.46)\end{array}$ & $\begin{array}{c}4.22 * * * \\
(0.63)\end{array}$ & $\begin{array}{c}1.76^{* * *} \\
(0.20)\end{array}$ \\
\hline Satisfaction democracy & $\begin{array}{c}-1.65 * * * \\
(0.34)\end{array}$ & $\begin{array}{c}0.18 \\
(0.22)\end{array}$ & $\begin{array}{c}0.70 * * * \\
(0.19)\end{array}$ & $\begin{array}{c}-0.78 * * * \\
(0.29)\end{array}$ & $\begin{array}{c}0.16 \\
(0.16)\end{array}$ \\
\hline Law and order & $\begin{array}{c}0.06 \\
(0.34)\end{array}$ & $\begin{array}{l}0.58 * \\
(0.32)\end{array}$ & $\begin{array}{c}0.96 * * * \\
(0.25)\end{array}$ & $\begin{array}{c}0.53 \\
(0.33)\end{array}$ & $\begin{array}{c}0.37 * * \\
(0.16)\end{array}$ \\
\hline Essential to live in a democracy & $\begin{array}{l}-0.40 \\
(0.37)\end{array}$ & $\begin{array}{l}-0.59 \\
(0.40)\end{array}$ & $\begin{array}{c}-0.82 * * \\
(0.37)\end{array}$ & $\begin{array}{l}-0.39 \\
(0.44)\end{array}$ & $\begin{array}{c}-0.84 * * * \\
(0.15)\end{array}$ \\
\hline Immigration & $\begin{array}{c}0.14 \\
(0.37)\end{array}$ & $\begin{array}{c}0.32 \\
(0.35)\end{array}$ & $\begin{array}{c}-1.45 * * * \\
(0.31)\end{array}$ & $\begin{array}{c}-1.87 * * * \\
(0.51)\end{array}$ & $\begin{array}{l}-0.27 \\
(0.21)\end{array}$ \\
\hline Constant & $\begin{array}{c}-3.59 * * * \\
(0.99)\end{array}$ & $\begin{array}{c}-5.38 * * * \\
(1.18)\end{array}$ & $\begin{array}{c}-3.61 * * * \\
(0.82)\end{array}$ & $\begin{array}{c}-3.23 * * * \\
(1.20)\end{array}$ & $\begin{array}{c}-0.94 * * * \\
(0.31)\end{array}$ \\
\hline Observations & 1,231 & 1,188 & 1,230 & 1,105 & 1,195 \\
\hline Pseudo R2 & 0.2388 & 0.2396 & 0.3151 & 0.2839 & 0.1203 \\
\hline
\end{tabular}

Robust standard errors in parentheses $* * * \mathrm{p}<0.01, * * \mathrm{p}<0.05, * \mathrm{p}<0.1$ 
Table A1. Logistic regression voted Bolsonaro vs others and vs Haddad

\begin{tabular}{|c|c|c|c|c|}
\hline & $\begin{array}{c}\text { Bolsonaro } \\
v s \text { others }\end{array}$ & $\begin{array}{c}\text { Bolsonaro } \\
v s \text { others }\end{array}$ & $\begin{array}{l}\text { Bolsonaro } \\
v s \text { Haddad }\end{array}$ & $\begin{array}{l}\text { Bolsonaro } \\
v s \text { Haddad }\end{array}$ \\
\hline Gender ( $1=$ female $)$ & $\begin{array}{c}-0.47 * * * \\
(0.16)\end{array}$ & $\begin{array}{c}-0.47 * * \\
(0.19)\end{array}$ & $\begin{array}{c}-0.47 * * \\
(0.18)\end{array}$ & $\begin{array}{l}-0.44^{*} \\
(0.26)\end{array}$ \\
\hline \multicolumn{5}{|l|}{ Age $($ baseline $=+65$ ) } \\
\hline $18-24$ & $\begin{array}{l}-0.01 \\
(0.38)\end{array}$ & $\begin{array}{c}0.03 \\
(0.45)\end{array}$ & $\begin{array}{l}-0.14 \\
(0.46)\end{array}$ & $\begin{array}{l}-0.19 \\
(0.62)\end{array}$ \\
\hline $25-39$ & $\begin{array}{c}0.32 \\
(0.35)\end{array}$ & $\begin{array}{c}0.46 \\
(0.41)\end{array}$ & $\begin{array}{c}0.29 \\
(0.41)\end{array}$ & $\begin{array}{c}0.62 \\
(0.58)\end{array}$ \\
\hline $40-54$ & $\begin{array}{c}0.17 \\
(0.34)\end{array}$ & $\begin{array}{c}0.20 \\
(0.40)\end{array}$ & $\begin{array}{c}0.13 \\
(0.40)\end{array}$ & $\begin{array}{c}0.28 \\
(0.56)\end{array}$ \\
\hline $54-64$ & $\begin{array}{c}0.17 \\
(0.38)\end{array}$ & $\begin{array}{c}0.10 \\
(0.46)\end{array}$ & $\begin{array}{c}0.10 \\
(0.45)\end{array}$ & $\begin{array}{c}0.07 \\
(0.62)\end{array}$ \\
\hline \multicolumn{5}{|l|}{ Education $(1=$ low $)$} \\
\hline Medium & $\begin{array}{c}0.12 \\
(0.19)\end{array}$ & $\begin{array}{l}-0.09 \\
(0.23)\end{array}$ & $\begin{array}{c}0.21 \\
(0.22)\end{array}$ & $\begin{array}{c}0.04 \\
(0.30)\end{array}$ \\
\hline High & $\begin{array}{c}-0.51^{* *} \\
(0.24)\end{array}$ & $\begin{array}{c}-0.77 * * * \\
(0.27)\end{array}$ & $\begin{array}{l}-0.24 \\
(0.28)\end{array}$ & $\begin{array}{l}-0.64 * \\
(0.37)\end{array}$ \\
\hline Unemployed & $\begin{array}{c}-0.57 * * \\
(0.22)\end{array}$ & $\begin{array}{l}-0.45^{*} \\
(0.25)\end{array}$ & $\begin{array}{c}-0.59^{* *} \\
(0.26)\end{array}$ & $\begin{array}{l}-0.46 \\
(0.33)\end{array}$ \\
\hline Income & $\begin{array}{c}1.12 * * * \\
(0.39)\end{array}$ & $\begin{array}{l}-0.20 \\
(0.49)\end{array}$ & $\begin{array}{c}2.31 * * * \\
(0.49)\end{array}$ & $\begin{array}{l}1.24 \% \\
(0.66)\end{array}$ \\
\hline \multicolumn{5}{|l|}{ Race (baseline=black) } \\
\hline Brown & $\begin{array}{c}0.65 * * * \\
(0.24)\end{array}$ & $\begin{array}{l}0.56^{*} \\
(0.29)\end{array}$ & $\begin{array}{c}0.94 * * * \\
(0.27)\end{array}$ & $\begin{array}{l}0.91 * * \\
(0.42)\end{array}$ \\
\hline White & $\begin{array}{c}0.83 * * * \\
(0.25)\end{array}$ & $\begin{array}{l}0.53^{*} \\
(0.31)\end{array}$ & $\begin{array}{c}1.29 * * * \\
(0.30)\end{array}$ & $\begin{array}{c}1.31 * * * \\
(0.46)\end{array}$ \\
\hline Yellow & $\begin{array}{c}0.57 \\
(0.48)\end{array}$ & $\begin{array}{l}0.87 * \\
(0.52)\end{array}$ & $\begin{array}{c}0.64 \\
(0.56)\end{array}$ & $\begin{array}{l}1.15 * \\
(0.67)\end{array}$ \\
\hline Indian & $\begin{array}{c}0.72 \\
(0.46)\end{array}$ & $\begin{array}{c}0.33 \\
(0.65)\end{array}$ & $\begin{array}{l}0.83^{*} \\
(0.49)\end{array}$ & $\begin{array}{c}0.82 \\
(0.86)\end{array}$ \\
\hline \multicolumn{5}{|l|}{ Religion (baseline $=$ other) } \\
\hline Catholic & $\begin{array}{l}-0.29 \\
(0.21)\end{array}$ & $\begin{array}{l}-0.06 \\
(0.26)\end{array}$ & $\begin{array}{l}-0.27 \\
(0.24)\end{array}$ & $\begin{array}{c}0.06 \\
(0.39)\end{array}$ \\
\hline Evangelist & $\begin{array}{c}0.56 * * \\
(0.23)\end{array}$ & $\begin{array}{l}0.61 * * \\
(0.28)\end{array}$ & $\begin{array}{c}0.85 * * * \\
(0.28)\end{array}$ & $\begin{array}{l}1.06 * * \\
(0.43)\end{array}$ \\
\hline Economic situation & $\begin{array}{c}0.44 * * * \\
(0.16)\end{array}$ & $\begin{array}{c}0.31 \\
(0.20)\end{array}$ & $\begin{array}{c}0.85^{* * *} * \\
(0.20)\end{array}$ & $\begin{array}{c}1.02 * * * \\
(0.27)\end{array}$ \\
\hline Ideology & $\begin{array}{c}1.66^{* * * *} \\
(0.24)\end{array}$ & $\begin{array}{c}1.60 * * * \\
(0.28)\end{array}$ & $\begin{array}{c}1.64 * * * \\
(0.28)\end{array}$ & $\begin{array}{c}1.90 * * * \\
(0.38)\end{array}$ \\
\hline Satisfaction democracy & $\begin{array}{c}0.17 \\
(0.20)\end{array}$ & $\begin{array}{c}0.05 \\
(0.25)\end{array}$ & $\begin{array}{c}0.24 \\
(0.24)\end{array}$ & $\begin{array}{l}-0.05 \\
(0.38)\end{array}$ \\
\hline Essential live democracy & $\begin{array}{c}-0.90 * * * \\
(0.18)\end{array}$ & $\begin{array}{c}-0.70^{* * *} \\
(0.22)\end{array}$ & $\begin{array}{c}-0.97 * * * \\
(0.22)\end{array}$ & $\begin{array}{c}-0.67^{* *} \\
(0.31)\end{array}$ \\
\hline Law and order & $\begin{array}{l}0.45^{* *} \\
(0.19)\end{array}$ & $\begin{array}{c}0.16 \\
(0.23)\end{array}$ & $\begin{array}{c}0.73 * * * \\
(0.23)\end{array}$ & $\begin{array}{c}0.73 * * \\
(0.31)\end{array}$ \\
\hline Immigration & $\begin{array}{l}-0.45^{*} \\
(0.25)\end{array}$ & $\begin{array}{c}-0.85 * * * \\
(0.31)\end{array}$ & $\begin{array}{l}-0.02 \\
(0.29)\end{array}$ & $\begin{array}{l}-0.50 \\
(0.40)\end{array}$ \\
\hline Corruption & $\begin{array}{c}-1.12^{* *} \\
(0.48)\end{array}$ & $\begin{array}{l}-0.77 \\
(0.69)\end{array}$ & $\begin{array}{c}-1.26 * * \\
(0.54)\end{array}$ & $\begin{array}{l}-0.25 \\
(0.78)\end{array}$ \\
\hline Inequality & $\begin{array}{c}0.34 \\
(0.33)\end{array}$ & $\begin{array}{c}0.57 \\
(0.39)\end{array}$ & $\begin{array}{c}0.05 \\
(0.40)\end{array}$ & $\begin{array}{c}0.35 \\
(0.54)\end{array}$ \\
\hline Anti-PT sentiment & & $\begin{array}{c}-3.70 * * * \\
(0.28)\end{array}$ & & $\begin{array}{c}-5.11 * * * \\
(0.40)\end{array}$ \\
\hline Constant & $\begin{array}{c}-1.24 * * \\
(0.52)\end{array}$ & $\begin{array}{c}0.83 \\
(0.64)\end{array}$ & $\begin{array}{c}-1.86^{* * *} \\
(0.61)\end{array}$ & $\begin{array}{c}0.01 \\
(0.79)\end{array}$ \\
\hline Observations & 882 & 854 & 701 & 678 \\
\hline Pseudo R2 & 0.1544 & 0.3561 & 0.2121 & 0.5350 \\
\hline
\end{tabular}

